\title{
Pengembangan Model Penilaian Sekolah Efektif
}

\author{
Subandi*
}

\begin{abstract}
Abstrak
A general purpose of the programe is for developing model of effective school assessment with its instrument and guidance of its application in order to do self-evaluation and self improvement, and effectiveness improvement of school organization functions toward being able to product out puts quality which hoped. A specific purpose of the programe is for developing; (1) construction and indicators of effective school, (2) several instruments for assessing effective school, (3) system of effective school assessment and its application guidance, and (4) recommendation of implementation for assessing effective school. This development is related more deeply with improving educational quality in school. Therefore, educational quality in school is a function of quality in put showing student's potentialities, quality of learning experience showing teacher's professional ability, quality of using learning facilities, and quality of headmaster leadership showing school culture.
\end{abstract}

Keywords: model of effective school assessment, indicators, assessment instrument, assessment guidence, educational quality, professional teacher, learning facilities, school culture, and school based management.

Penulis adalah dosen dan Pembantu Ketua I STAI Ma'arif Metro Lampung

NO. 2. VOL. I. 2008

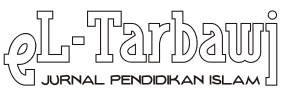




\section{A. Pendahuluan}

Keunggulan suatu bangsa tidak lagi bertumpu pada kekayaan alam, melainkan pada keunggulan sumber daya manusia (SDM), yaitu tenaga terdidik yang mampu menjawab tantangan-tantangan yang sangat cepat. Sejumlah pembicara dalam berbagai seminar, diskusi atau tulisan di media masa mengisyaratkan bahwa secara keseluruhan, mutu SDM Indonesia saat ini masih ketinggalan dan berada di belakang SDM negara-negara maju dan negara-negara tetangga, seperti Malaysia dan Thailand.

Kenyataan ini sudah lebih dari cukup untuk mendorong pakar dan praktisi pendidikan melakukan kajian sistematik untuk membenahi atau memperbaiki sistem pendidikan nasional (Brighthouse, J. \& Woods, D. 1999:21). Agar keluaran sekolah mampu beradaptasi secara dinamis dengan perubahan dan tantangan itu, pemerintah melontarkan gagasan tentang manajemen pendidikan yang berbasis sekolah (school-based management) yang memberikan ruang yang luas bagi sekolah dan masyarakat untuk menentukan program dan rencana pengembangan sendiri sesuai dengan kebutuhan dan kondisi masing-masing. Sejalan dengan gagasan desentralisasi pengelolaan pendidikan, maka fungsifungsi pengelolaan sekolah perlu diberdayakan secara maksimal agar dapat berjalan secara efektif untuk menghasilkan mutu lulusan yang diharapkan oleh masyarakat dan bangsa.

Implementasi gagasan tersebut perlu didukung oleh seperangkat instrumen yang akan mendorong sekolah berupaya meningkatkan efektivitas fungsi-fungsi pengelolaannya secara terus-menerus sehingga mampu berkembang menjadi learning organization (O’Nell, 1995:3). Model penilaian sekolah efektif (MPSE) merupakan salah satu instrumen yang diharapkan dapat digunakan oleh pengelola pendidikan untuk mengetahui tingkat keberhasilan setiap sekolah. Hasil penilaian tersebut selanjutnya dapat dijadikan bahan pertimbangan untuk melakukan upaya perbaikan sekolah.

Kegiatan ini bertujuan untuk mengembangkanMPSEbeserta instrumen dan pedoman pelaksanaannya. Dalam jangka panjang, MPSE diharapkan dapat memacu setiap sekolah untuk melakukan penilaian sendiri (selfevaluation) dan melakukan perbaikan-perbaikan yang diperlukan secara 
berkala untuk meningkatkan efektivitas fungsi-fungsi pengelolaannya, sehingga MPSE mampu menjadikan setiap sekolah menghasilkan mutu lulusan yang diharapkan. Lebih khusus, kegiatan ini juga bertujuan untuk mengembangkan: (1) konstruk dan indikator sekolah efektif, (2) instrumen penilaian sekolah efektif, (3) sistem penilaian sekolah efektif dan pedoman pelaksanaannya (termasuk penafsiran hasilnya), (4) layanan kegiatan, dan (5) usulan implementasi penilaian sekolah efektif.

Pengembangan MPSE diharapkan menghasilkan: (1) Konstruk dan Indikator Sekolah Efektif, yaitu suatu konstruk dan sejumlah indikator tentang penilaian sekolah efektif yang memiliki landasan konseptual yang kuat (theoretically sound) serta sesuai dengan kondisi dan budaya serta karakteristik sekolah di Indonesia; (2) Instrumen Penilaian Sekolah Efektif, yaitu penyusunan instrumen tersebut merujuk pada sifat umum yang berlaku bagi setiap sekolah, dan sifat khusus yang berlaku bagi sekolah yang memiliki karakteristik khusus seperti kejuruan dan keagamaan; (3) Pedoman Pelaksanaan Penilaian Sekolah Efektif dan Penafsiran Hasilnya, yaitu pedoman yang dirancang dengan mengacu pada konstruk sistem persekolahan dan instrumen penilaian yang dikembangkan. Rumusan pedoman pelaksanaan penilaian tersebut yang berisi: (a) penjelasan singkat tentang konstruk dan instrumen penilaian sekolah efektif, (b) prosedur pelaksanaan penilaian, (c), prosedur penskoran setiap instrumen dan penafsiran hasilnya, dan (d) implikasi hasil penilaian bagi upaya peningkatan efektivitas sekolah; (4) Laporan Kegiatan, yaitu hasil kegiatan berupa laporan yang akan memuat prosedur kegiatan, kajian teoritis dan survei lapangan, serta hasil yang diperoleh terdiri atas: (a) tujuan kegiatan, (b) pengembangan konstruk dan indikator sekolah efektif, (c) pengembangan instrumen penilaian sekolah efektif, dan (d) pengembangan pedoman penilaian sekolah efektif; dan (5) Usulan Implementasi Penilaian Sekolah Efektif, yaitu suatu usulan yang dirumuskan dengan mengacu pada produk-produk yang telah dihasilkan yang mencakup rasional, penjelasan tentang konsep dan instrumen penilaian sekolah efektif, strategi pelaksanaan penilaian sekolah efektif, organisasi penyelenggaraan, dan rencana anggaran. 


\section{B. Konsep Sekolah Efektif}

Esensi yang terkandung dalam bagian pendahuluan di atas adalah fungsi sekolah sebagai tempat belajar yang memiliki kewajiban untuk menyelenggarakan pengalaman pembelajaran yang bermutu bagi peserta didiknya. Esensi inilah yang menjadi misi atau tugas pokok sekolah, yang sepatutnya menjadi dasar bagi peserta didiknya dan analisis kinerja sekolah yang efektif (Barrow, R., 1986:87). Sekolah efektif dapat diartikan sebagai sekolah yang menunjukkan tingkat kinerja yang diharapkan dalam menyelenggarakan proses belajarnya, dengan menunjukkan hasil belajar yang bermutu pada peserta didik sesuai dengan tugas pokoknya (Levine, 1994:12). Mutu pembelajaran dan hasil belajar yang memuaskan tersebut merupakan produk akumulatif dari seluruh layanan yang dilakukan sekolah dan pengaruh dari suasana/iklim yang kondusif yang diciptakan di sekolah. Berbagai perspektif dapat dikemukakan berikut ini.

\section{Pengertian Sekolah Efektif}

Kajian sejumlah literatur yang membahas tentang sekolah efektif akan dijumpai rumusan pengertian yang bermacam-macam. Sekolah efektif menurut Prince George County Public Schools (Taylor, 1990:118) adalah sekolah yang semua sumber dayanya diorganisasikan dan dimanfaatkan untuk menjamin semua siswa, tanpa memandang ras, jenis kelamin, maupun status sosial-ekonomi, dapat mempelajari materi kurikulum yang esensial di sekolah itu. Rumusan pengertian ini lebih diorientasikan pada pengoptimalan pencapaian tujuan pendidikan sebagaimana termuat kurikulum.

Pengertian lain tentang sekolah efektif dikemukakan oleh Cheng (1994:83) yakni sekolah efektif menunjukkan pada kemampuan sekolah dalam menjalankan fungsinya secara maksimal, baik fungsi ekonomis, fungsi sosial-kemanusiaan, fungsi politis, fungsi budaya maupun fungsi pendidikan. Fungsi ekonomis sekolah adalah memberi bekal kepada siswa agar dapat melakukan aktivitas ekonomi sehingga dapat hidup sejahtera. Fungsi sosial kemanusiaan sekolah adalah sebagai media bagi siswa untuk beradaptasi dengan kehidupan masyarakat. Fungsi politis sekolah adalah sebagai wahana untuk memperoleh pengetahuan tentang hak dan kewajiban 
sebagai warga negara. Fungsi budaya adalah media untuk melakukan transmisi dan transformasi budaya. Adapun fungsi pendidikan adalah sekolah sebagai wahana untuk proses pendewasaan dan pembentukkan kepribadian siswa.

Dengan memperhatikan empat pilar pendidikan di atas, berbagai kelemahanyangberkembangdimasyarakat, dandenganmempertimbangkan akar budaya masyarakat yang menjunjung tinggi nilai-nilai Agama, maka sekolah di Indonesia seharusnya dikembangkan untuk membantu siswanya menguasai kompetensi yang berguna bagi kehidupannya di masa depan, yaitu: (a) kompetensi keagamaan, meliputi pengetahuan, sikap dan keterampilan keagamaan yang diperlukan untuk dapat menjalankan fungsi manusia sebagai hamba Allah Yang Mahakuasa dalam kehidupan seharihari, (b) kompetensi akademik, meliputi pengetahuan, sikap, kemampuan, dan keterampilan yang diperlukan untuk dapat mengikuti perkembangan ilmu pengetahuan dan teknologi sesuai dengan jenjang pendidikannya, (c) kompetensi ekonomi, meliputi pengetahuan, sikap, dan keterampilan yang diperlukan untuk dapat memenuhi kebutuhan ekonomi agar dapat hidup layak di dalam masyarakat, dan (d) kompetensi sosial pribadi, meliputi pengetahuan, sistem nilai, sikap dan keterampilan untuk dapat hidup adaptif sebagai warga negara dan warga masyarakat internasional yang demokratis.

Sekolah harus dipahami sebagai satu kesatuan sistem pendidikan yang terdiri atas sejumlah komponen yang saling bergantung satu sama lain. Dengan demikian, pengembangan kompetensi pada diri siswa tidak dapat diserahkan hanya pada kegiatan belajar-mengajar (KBM) di kelas, melainkan juga pada iklim kehidupan dan budaya sekolah secara keseluruhan. Setiap sekolah sebagai suatu kesatuan diharapkan mampu memberikan pengalaman belajar kepada seluruh siswanya untuk menguasai keempat kompetensi di atas sesuai dengan jenjang pendidikannya dan misi khusus yang diembannya.

\section{Konstruk Sekolah Efektif}

Di negara-negara maju, seperti Amerika Serikat, Inggris, Jepang dan Australia, penelitian tentang sekolah efektif telah menghasilkan sejumlah temuan tentang berbagai ciri dan indikator sekolah efektif. Ciri-ciri dan 
indikator-indikator itu bisa digunakan sebagai dasar untuk mengenali atau bahkan untuk mengembangkan instrumen penilaian sekolah efektif. Di bawah ini adalah contoh tentang rumusan ciri-ciri dan indikator sekolah efektif berdasarkan hasil penelitian di Amerika Serikat yang dilakukan di Glendale Union High School. Amerika Serikat telah menghasilkan rumusan tentang ciri-ciri dan indikator keefektifan sekolah yang termasuk lengkap (Taylor,1990:13; Joyce et al., 1999:17). Dari rumusan ini selain ditampilkan sejumlah ciri yang bisa digunakan untuk mengenali apakah suatu sekolah termasuk efektif, juga pada setiap ciri diidentifikasi sejumlah indikator yang bisa digunakan untuk mengenali keberadaan dari setiap ciri itu. Ciri-ciri dan indikator efektivitas sekolah itu ditampilkan pada tabel berikut ini.

Tabel 1 Ciri-ciri dan Indikator Efektivitas Sekolah

\begin{tabular}{|c|c|}
\hline Ciri-ciri & Indikator \\
\hline $\begin{array}{l}\text { Tujuan sekolah dinyatakan } \\
\text { secara jelas dan spesifik }\end{array}$ & $\begin{array}{l}\text { Tujuan sekolah : } \\
\text { - } \quad \text { Dinyatakan secara jelas } \\
\text { - } \quad \text { Digunakan untuk pengambilan keputusan } \\
\text { - } \quad \text { Dipahami oleh siswa, guru, dan staf }\end{array}$ \\
\hline $\begin{array}{l}\text { Pelaksanaan kepemimpinan } \\
\text { pendidikan yang kuat oleh } \\
\text { Kepala Sekolah }\end{array}$ & $\begin{array}{l}\text { Kepala Sekolah : } \\
\text { - } \quad \text { Bisa dihubungi dengan mudah } \\
\text { Bersikap responsif kepada guru, staf, dan } \\
\text { - } \quad \text { Reswa } \\
\text { - } \quad \text { Melaksansif kepada orang tua dan masyarakat } \\
\quad \text { pada pembemiajaran } \\
\text { Menjaga agar rasio antara guru/siswa sesuai } \\
\text { dengan rasio ideal }\end{array}$ \\
\hline Ekspektasi guru dan staf tinggi & $\begin{array}{l}\text { Guru dan staf: } \\
\text { - } \quad \text { Yakin bahwa semua siswa bisa belajar dan } \\
\text { berprestasi } \\
\text { - } \quad \text { Menekankan pada hasil akademis } \\
\text { - Memandang guru sebagai penentu terpenting } \\
\text { bagi keberhasilan siswa }\end{array}$ \\
\hline $\begin{array}{l}\text { Ada kerja sama kemitraan } \\
\text { antara sekolah, orang tua dan } \\
\text { masyarakat }\end{array}$ & $\begin{array}{ll}\text { Sekolah : } \\
\text { - } \quad \text { Komunikasi secara positif dengan orang tua } \\
\text { - } \quad \text { Memelihara jaminan dukungan orang tua } \\
\text { - } \quad \text { Bekerjasama dengan orang tua dan } \\
\text { masyarakat } \\
\text { - } \quad \text { Berbagi tanggung jawab untuk menegakkan } \\
\text { disiplin dan mempertahankan keberhasilan } \\
\text { - } \quad \text { Menghadiri acara-acara penting di sekolah }\end{array}$ \\
\hline
\end{tabular}




\begin{tabular}{|c|c|}
\hline Ciri-ciri & Indikator \\
\hline $\begin{array}{l}\text { Adanya iklim positif dan } \\
\text { kondusif bagi siswa untuk } \\
\text { belajar }\end{array}$ & $\begin{array}{l}\text { Sekolah : } \\
\text { - Rapi, bersih, dan aman secara fisik } \\
\text { - } \quad \text { Mipelihara secara baik } \\
\text { berperi penghargaan kepada yang } \\
\text { - Memberi penguatan terhadap perilaku positif } \\
\text { siswa } \\
\text { Siswa : } \\
\text { Mentaati aturan sekolah dan aturan } \\
\text { - Memerintah daerah } \\
\text { Menjalankan tugas/kewajiban tepat waktu }\end{array}$ \\
\hline $\begin{array}{l}\text { Kemajuan siswa sering } \\
\text { dimonitor }\end{array}$ & $\begin{array}{l}\text { Guru memberi siswa : } \\
\text { - } \quad \text { Tugas yang tepat } \\
\text { - } \quad \text { Keman balik secara cepat (segera) } \\
\text { optimal } \\
\text { - Penilaian hasil belajar dari berbagai segi }\end{array}$ \\
\hline $\begin{array}{l}\text { Menekankan kepada } \\
\text { keberhasilan siswa dalam } \\
\text { mencapai keterampilan aktifitas } \\
\text { yang esensial }\end{array}$ & $\begin{array}{l}\text { Siswa : } \\
\text { Melakukan hal yang terbaik untuk mencapai } \\
\text { hasil belajar yang optimal, baik yang bersifat } \\
\text { akademis maupun nonakademis } \\
\text { - Memperoleh berbagai keterampilan yang } \\
\text { esensial } \\
\text { Kepala Sekolah : } \\
\text { - Menunjukkan komitmen dalam mendukung } \\
\text { program keterampilan esensial } \\
\text { Guru : } \\
\text { - Menerima bahan yang memadai untuk } \\
\quad \text { mengajarkan keterampilan yang esensial }\end{array}$ \\
\hline $\begin{array}{l}\text { Komitmen yang tinggi dari } \\
\text { SDM sekolah terhadap program } \\
\text { pendidikan }\end{array}$ & $\begin{array}{l}\text { Guru : } \\
\text { - Membantu merumuskan dan melaksanakan } \\
\text { - } \quad \text { Menuan pengembangan sekolah } \\
\text { - Menukkan profesionalisme dalam bekerja }\end{array}$ \\
\hline
\end{tabular}

Berdasarkan kajian terhadap sejumlah hasil penelitian tentang sekolah efektif di berbagai negara seperti Australia, Amerika Serikat, Belanda. dan Inggris dirumuskan 10 karateristik sekolah efektif, yaitu: 
Tabel 2 Karakteristik Sekolah Efektif

\begin{tabular}{|c|c|c|}
\hline No & Aspek & Indikator \\
\hline 1 & Profesional leadership & $\begin{array}{l}\text { - } \quad \text { Firm and Purposeful } \\
\text { - } \quad \text { A participate approach } \\
\text { The leading professional }\end{array}$ \\
\hline 2 & Shared vision and goals & $\begin{array}{l}\text { - } \quad \text { Unity of purpose } \\
\text { - } \quad \text { Consistency of practice } \\
\text { Collegiality and collaboration }\end{array}$ \\
\hline 3 & A learning environment & $\begin{array}{l}\text { - An orderly atmosphere } \\
\text { - An attractive working environment } \\
\text { - Maximization of learning time }\end{array}$ \\
\hline 4 & Learning & $\begin{array}{l}\text { - Academic emphasis } \\
\text { - Focus on achievement }\end{array}$ \\
\hline 5 & Purposeful teaching & $\begin{array}{ll}\text { - } & \text { High expectation all round } \\
\text { - } & \text { Communication expectations } \\
& \text { Providing intellectual challenge }\end{array}$ \\
\hline 6 & Positive reinforcement & $\begin{array}{l}\text { - Clear and fair discipline } \\
\text { - Feedback }\end{array}$ \\
\hline 7 & Monitoring progress & $\begin{array}{l}\text { - } \quad \text { Monitoring pupil performance } \\
\text { Evaluating school performance }\end{array}$ \\
\hline 8 & $\begin{array}{l}\text { Pupils right and } \\
\text { responsibilities }\end{array}$ & $\begin{array}{ll}\text { - } & \text { Raising pupil self-esteem } \\
\text { - } & \text { Positions of responsibility } \\
& \text { Control of work }\end{array}$ \\
\hline 9 & Home/school partnership & $\begin{array}{l}\text { - Parental involvement in their children's } \\
\text { learning }\end{array}$ \\
\hline 10 & A Learning organization & - School-based staff development \\
\hline
\end{tabular}

Bank Dunia (1998), dalam laporannya tentang pengalaman dalam melakukan Education Quality Improvement Program di Kamboja, mengidentifikasi empat kelompok karateristik sekolah efektif, yaitu: (1) Supporting inputs yang meliputi dukungan orang tua dan masyarakat, lingkungan belajar yang sehat, dukungan yang efektif dari sistem pendidikan, serta kelengkapan buku dan sumber belajar yang memadai; (2) Enabling condition yang meliputi kepemimpinan yang efektif tenaga guru yang kompeten, fleksibilitas dan otonomi serta waktu di sekolah yang lama; (3) School climate yang meliputi harapan siswa yang tinggi, sikap guru yang positif, keteraturan dan disiplin, kurikulum yang terorganisasi. 
Sistem reward dan insentif bagi siswa dan guru, serta tuntutan waktu belajar yang tinggi; dan (4) Teaching-learning process yang meliputi strategi mengajar yang bervariasi, pekerjaan rumah yang sering, penilaian dan umpan balik yang sering, dan partisipasi (kehadiran, penyelesaian studi, kelanjutan studi) siswa terutama perempuan.

Uraian di atas menggambarkan keragaman rumusan tentang karakteristik umum (common denominators) yang ditemukan di sekolahsekolah yang tergolong efektif di sejumlah negara. Keragaman rumusan tersebut, antara lain, dipengaruhi oleh konteks budaya setempat, dasar filosofis, tujuan dan fungsi sekolah, serta asumsi tentang variabel-variabel yang dominan dalam menentukan keefektifan sekolah.

\section{Pengembangan Model Penilaian Sekolah Efektif}

Upaya pengembangan MPSE terutama dimaksudkan untuk mengelaborasi konsep-konsep atau rujukan-rujukan teoritis tentang sekolah efektif, mengkaji dan menjabarkan lebih rinci tentang strategi dan langkah-langkah studi melalui diskusi kelompok terfokus. Kajian terhadap konsep yang dikembangkan di negara lain dipadukan dengan kondisi dan iklim yang terdapat di sekolah-sekolah sehingga dapat dirumuskan konsep tentang sekolah efektif yang dapat dipertanggungjawabkan secara teoritis dan dapat dilaksanakan secara realistis.

Berdasarkan kajian tersebut dapat dirumuskan konstruk tentang sekolah efektif untuk dijadikan landasan konseptual dalam menuangkan indikator sekolah efektif. Merujuk pada hasil-hasil yang diharapkan dari kegiatan pengembangan model penilaian sekolah efektif ditempuh beberapa langkah. Langkah-langkah yang dilakukan meliputi: (a) pengembangan konstruk dan instrumen sekolah efektif, (b) mengembangkan sistem penilaian sekolah efektif, (c) menyusun pedoman pelaksanaan penilaian sekolah efektif dan penafsirannya, dan (d) mengembangkan usulan implementasi penilaian sekolah efektif. Visualisasi pendekatan yang 
dikembangkan dalam kegiatan ini dapat dilihat pada Gambar 1.

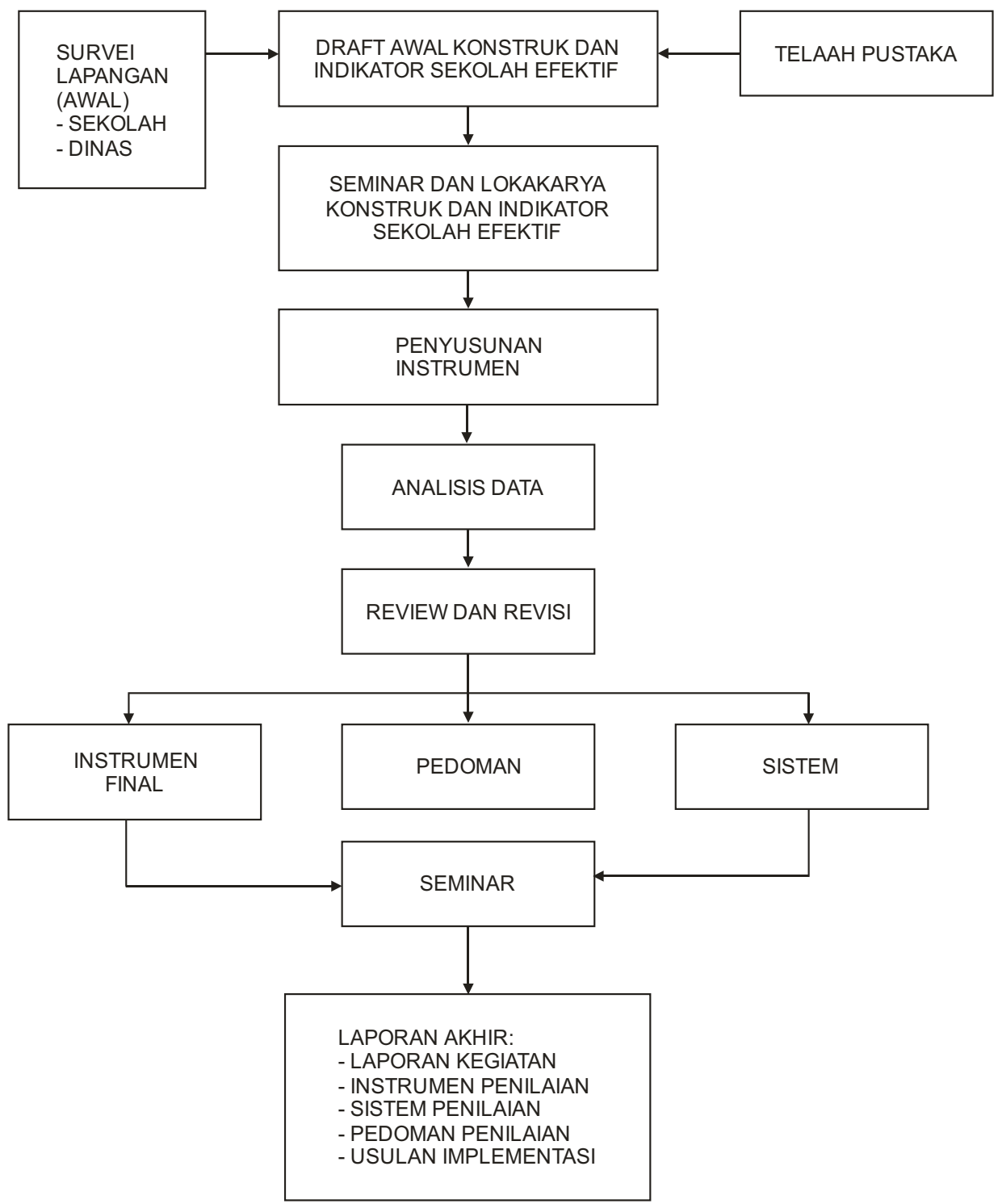

Gambar 1 Pengembangan Model Penilaian Sekolah Efektif 


\section{Pengembangan Konstruk dan Instrumen Sekolah Efektif}

Untuk menghasilkan rumusan konstruk sekolah efektif yang akan dijadikan landasan dalam mengembangkan instrumen dilakukan beberapa langkah kegiatan. Kegiatan yang dilakukan merupakan perpaduan antara kajian konseptual dengan survei lapangan untuk selanjutnya diseminarkan dengan mengundang beberapa pakar di bidangnya. Rumusan konstruk yang telah teruji selanjutnya dijabarkan menjadi beberapa indikator untuk kemudian dijadikan bahan dalam membuat kisi-kisi. Secara rinci langkahlangkah kegiatan yang ditempuh diuraikan sebagai berikut:

a. Kajian Konseptual. Kegiatan-kegiatan yang dilakukan pada tahap persiapan ini adalah sebagai berikut: (a) curah pendapat tentang konsep sekolah efektif, (b) penelaahan rujukan-rujukan konseptual tentang sekolah efektif, (c) pengkajian dan penjabaran lebih rinci tentang strategi dan langkah-langkah pengembangan model penilaian sekolah efektif, dan (d) pengembangan panduan diskusi kelompok kecil.

b. Survei Lapangan. Pemikiran awal tentang sekolah efektif yang telah ditemukan dalam kajian konseptual kemudian dikonfirmasi melalui survei lapangan kepada pihak-pihak yang selama ini terkait dengan penilaian kepada sekolah. Subjek yang dijadikan sasaran dalam survei ini adalah sekolah yang termasuk pada SLTP, SMU, dan kategori sekolah khusus yang diwakili oleh sekolah kejuruan yang berbasis keagamaan. Selain melibatkan pihak sekolah, survei ini juga melibatkan lembaga yang terkait dengan penilaian pada sekolah dan beberapa tokoh masyarakat yang dianggap mempunyai kepedulian terhadap pendidikan. Survei ini menghasilkan suatu perbaikan terhadap konsep yang telah dirancang, sehingga konsep yang dirumuskan menjadi konsep yang secara realistis dapat dilaksanakan. Rumusan pada tahap ini selanjutnya dijadikan bahan untuk seminar dan lokakarya dengan para pakar.

c.Seminar dan Lokakarya. Agar konstruk dan instrumen penilaian sekolah efektif yang dikembangkan benar-benar teruji dan dapat diterapkan untuk kondisi persekolahan di Indonesia, masukan dari berbagai sumber yang dipandang relevan juga dihimpun melalui suatu seminar dan lokakarya dengan melibatkan kelompok yang lebih besar terdiri atas tim peneliti, beberapa pakar (akademisi) dalam bidang yang bersangkutan, praktisi dari lapangan terdiri dari pembuat kebijakan dan pihak sekolah (kepala 
sekolah, guru mata pelajaran, guru pembimbing, wakasek kesiswaan/guru pembinaan kesiswaan) secara proporsional dengan mempertimbangkan keterwakilan setiap sekolah.

Hasil yang diperoleh dari kegiatan seminar dan lokakarya ini adalah masukan dan komentar terhadap konsep dan indikator sekolah efektif seperti tertera di atas. Dengan demikian rancangan yang telah disusun oleh tim pengembang mendapat justifikasi dari para pakar dan praktisi di lapangan sebagai konsep yang telah teruji untuk dikembangkan lebih lanjut menjadi seperangkat instrumen. Rumusan akhir tentang konstruk sekolah efektif dijabarkan sebagai berikut. Efektivitas sekolah menggambarkan derajat keoptimalan berfungsinya semua sumber daya sekolah, baik sumber daya manusia maupun bukan manusia, dalam menghasilkan keluaran atau mencapai tujuan yang diharapkan secara maksimal. Sumber daya sekolah pada dasarnya disediakan untuk memberi pelayanan kepada siswa agar dapat memperoleh pengalaman belajar yang bermakna.

Memperhatikan fungsi-fungsi yang selama ini dilaksanakan oleh sekolah serta akar budaya masyarakat yang menjunjung tinggi nilai-nilai Agama, maka dirumuskan bahwa sekolah harus dapat membekali keluarannya dalam sejumlah kompetensi, yaitu: (a) Kompetensi keagamaan, kompetensi ini meliputi pengetahuan, sikap dan keterampilan keagamaan yang diperlukan untuk dapat menjalankan fungsi manusia sebagai hamba Allah Yang Mahakuasa dalam kehidupannya sehari-hari; (b) Kompetensi akademik, kompetensi akademik meliputi pengetahuan, sikap, kemampuan, dan keterampilan yang diperlukan untuk dapat mengikuti perkembangan ilmu pengetahuan ilmu pengetahuan dan teknologi sesuai dengan jenjang pendidikannya; (c) Kompetensi ekonomi, kompetensi ini meliputi pengetahuan, sikap, dan keterampilan yang diperlukan untuk dapat memenuhi kebutuhan ekonomi agar dapat hidup layak di dalam masyarakat; (d) Kompetensi sosial-pribadi, kompetensi ini mencakup pengetahuan, sistem nilai, sikap, dan keterampilan untuk dapat hidup adaptif sebagai warga negara dan warga masyarakat internasional yang demokratis yang mampu mengelola diri sendiri (intrapersonal) serta orang lain (interpersonal) dalam kehidupan masyarakat yang heterogen (plural).

Untuk dapat menilai efektivitas sekolah, perlu memperhatikan beberapa 
layanan yang diberikan oleh sekolah dalam memfasilitasi siswa untuk menguasai kompetensi yang dimaksud. Layanan-layanan yang seharusnya ada di setiap sekolah, yaitu layanan pembelajaran, layanan manajemen dan iklim sekolah, layanan bimbingan dan konseling, layanan pembinaan siswa dan ekstra kurikuler, serta layanan kemitraan sekolah-masyarakat.

d. Kisi-kisi Instrumen. Instrumen yang disusun terdiri atas dua jenis instrumen, yaitu angket dan pedoman wawancara/observasi. Instrumen pengumpul data yang berupa angket digunakan untuk penilaian sekolah efektif yang dilakukan oleh pihak sekolah (beserta unsurnya), instrumen yang berupa pedoman wawancara/observasi digunakan jika penilaian dilakukan oleh pihak di luar sekolah.

e. Penyusunan Butir Soal. Penyusunan butir soal dibuat berdasarkan indikatoryang telah disusun pada setiap layanan. Pertanyaan atau pernyataan pada setiap butir soal dalam setiap layanan disesuaikan dengan pengalaman responden yang akan memberikan penilaian terhadap layanan tersebut berdasarkan pada fungsi dari layanan tersebut terhadap responden yang dimaksud. Dengan demikian, untuk setiap layanan memuat jumlah butir soal yang tidak sama untuk setiap respondennya. Setiap item dibuat dalam bentuk pertanyaan atau pernyataan yang tertutup dengan empat pilihan. Pilihan yang disediakan disusun secara ordinal yang menggambarkan empat kualifikasi mulai dari yang tidak efektif, kurang efektif, efektif, dan sangat efektif. Responden diminta hanya memilih satu pilihan saja yang sesuai dengan pengalaman atau posisi dirinya maupun posisi sekolahnya.

f. Penimbangan dan Revisi Butir Soal. Butir soal yang telah disusun untuk setiap layanan selanjutnya ditimbang oleh pakar untuk menentukan nilai ordinal pada setiap pilihan dan memberikan koreksi terhadap pernyataan atau pertanyaan pada setiap butir soal. Penimbangan dilakukan oleh lima pakar pada bidangnya sehingga substansi dari setiap butir soal dapat dipertanggungjawabkan. Penimbangan terhadap pilihan yang belum menunjukkan ordinal antara satu sampai empat dijadikan bahan revisi untuk disusun kembali sehingga pilihan tersebut tatap berada pada rentang satu sampai empat. Selain penimbangan terhadap option, juga dilakukan koreksi terhadap pernyataan atau pertanyaan pada setiap butir soal. Koreksi yang diberikan tidak menyangkut masalah substansi, tetapi lebih bersifat redaksional seperti penyederhanaan kalimat dan penyusunan kalimat, 
sehingga tidak mengubah isi pernyataan atau pertanyaan tersebut. Dengan demikian, hasil penimbangan yang telah dilakukan tidak mengubah jumlah butir soal untuk setiap angket yang telah disusun.

g. Uji-coba Instrumen. Untuk angket, instrumen yang telah direvisi berdasarkan penimbangan para pakar, selanjutnya diujicobakan ke lapangan dengan mengambil sampel dari tiga propinsi, yaitu propinsi Jawa Barat, Jawa Tengah, dan Kalimantan Timur. Propinsi yang dipilih dipertimbangkan menurut propinsi yang berada di Jawa dan di luar Jawa dan katergorisasi pencapaian prestasi pendidikan pada setiap propinsi. Selain itu, penentuan sekolahnya diupayakan secara bervariasi yaitu SLTP, SMU, dan SMK dengan memperhatikan kualifikasi sekolah favorit (baik) dan nonfavorit (kurang baik). Diharapkan dengan variasi sekolah tersebut dapat diperoleh gambaran yang lebih signifikan mengenai daya pembeda instrumen yang telah disusun.

Responden pada setiap sekolah terdiri atas kepala sekolah, guru mata pelajaran, guru pembimbing, wakil kepala sekolah bidang kesiswaan atau guru pembina kesiswaan, siswa dan orang tua siswa masing-masing satu orang. Setiap angket yang sudah diuji-cobakan kemudian diberi skor berdasarkan nilai yang sudah ditentukan, sehingga diperoleh nilai untuk setiap layanan dari masing-masing responden. Skor ini kemudian diolah untuk menghasilkan data yang diperlukan dalam menguji instrumen.

Untuk Pedoman Wawancara/Observasi, instrumen yang berupa pedoman wawancara/observasi tidak diujicobakan ke lapangan, karena keterbatasan waktu yang tersedia untuk uji coba instrumen. Oleh karena itu, pedoman wawancara/observasi ditelaah dan dikaji oleh tim pengembang dengan memperhatikan masukan-masukan dari beberapa pihak.

h. Validitas Soal untuk Setiap Layanan. Untuk menguji validitas item pada setiap angket dilakukan analisis dengan menggunakan program SPSS. Langkah yang dilakukan adalah mengkorelasikan skor setiap item dengan skor total, hasil pengolahan menghasilkan data sebagai berikut.

i. Uji Beda setiap Layanan dengan Melihat Sekolah Favorit dan NonFavorit untuk setiap Layanan. Dengan menggunakan program SPSS diperoleh informasi bahwa seluruh item pada setiap layanan memiliki daya pembeda yang signifikan antara sekolah favorit dengan nonfavorit. 
j. Uji Beda setiap Layanan pada Seluruh Responden dengan Memperhatikan Sekolah Favorit dan Nonfavorit. Uji beda instrumen untuk setiap layanan dilakukan dengan membandingkan rata-rata antara skor setiap layanan dengan rata-rata nilai total pada layanan tersebut pada kelompok sekolah favorit dengan kelompok sekolah non favorit. Pengujian ini hanya dilakukan terhadap empat layanan yaitu layanan pembelajaran, manajemen dan iklim sekolah, bimbingan dan konseling serta kemitraan dengan masyarakat, sementara untuk layanan kesiswaan dan ekstrakurikuler tidak dapat dilakukan karena korelasi antarresponden yang menilainya rendah.

Secara visual perbandingan persentase keefektifan untuk setiap layanan antara sekolah favorit dengan sekolah nonfavorit dapat dilihat pada Tabel 3 dan 4 .

Tabel 3 Hasil Uji Beda Instrumen

\begin{tabular}{|c|l|c|c|l|}
\hline No & \multicolumn{1}{|c|}{ Layanan } & $\begin{array}{c}\text { Nilai Rata- } \\
\text { rata pada } \\
\text { Setiap Sekolah } \\
\text { Favorit }\end{array}$ & $\begin{array}{c}\text { Nilai Rata- } \\
\text { rata Setiap } \\
\text { Sekolah } \\
\text { Nonfavorit }\end{array}$ & Uji Beda \\
\hline 1. & Pembelajaran & 45,33 & 39,96 & Berbeda \\
\hline 2. & $\begin{array}{l}\text { Manajemen dan iklim } \\
\text { sekolah }\end{array}$ & 47,02 & 42,27 & Berbeda \\
\hline 3. & Bimbingan dan konseling & 42,65 & 35,04 & Berbeda \\
\hline 4. & $\begin{array}{l}\text { Kesiswaan dan ekstra- } \\
\text { kurikuler }\end{array}$ & 36,33 & 30,70 & Berbeda \\
\hline 5. & $\begin{array}{l}\text { Kemitraan dengan } \\
\text { masyarakat }\end{array}$ & 30,92 & 24,42 & Berbeda \\
\hline
\end{tabular}

Untuk menstandarkan hasil uji beda setiap layanan, skor yang diperoleh pada tabel di atas kemudian dibuat persentase efektivitas dari setiap layanan dengan rumus rata-rata skor setiap layanan dibagi skor ideal dikalikan $100 \%$. Dari hasil perhitungan dengan rumus tersebut diperoleh hasil seperti pada tabel berikut. 
Tabel 4 Persentase Efektivitas Setiap Layanan Antara Sekolah Favorit dan Nonfavorit

\begin{tabular}{|c|c|c|c|c|c|}
\hline NO & Layanan & $\begin{array}{l}\text { Jenis } \\
\text { Sekolah }\end{array}$ & $\begin{array}{c}\text { Skor } \\
\text { Rata-rata }\end{array}$ & $\begin{array}{l}\text { Skor } \\
\text { Ideal }\end{array}$ & $\begin{array}{l}\text { Persentase } \\
\text { Efektivitas }\end{array}$ \\
\hline \multirow[t]{2}{*}{1.} & \multirow[t]{2}{*}{ Pembelajaran } & $\mathrm{F}$ & 45,33 & \multirow{2}{*}{62,67} & $72,33 \%$ \\
\hline & & NF & 39,96 & & $63,38 \%$ \\
\hline \multirow[t]{2}{*}{2.} & \multirow{2}{*}{$\begin{array}{l}\text { Manajemen Sekolah dan } \\
\text { iklim sekolah }\end{array}$} & $\mathrm{F}$ & 47,02 & \multirow{2}{*}{62,67} & $75,04 \%$ \\
\hline & & NF & 42,27 & & $67,38 \%$ \\
\hline \multirow[t]{2}{*}{3.} & \multirow[t]{2}{*}{ Bimbingan dan Konseling } & $\mathrm{F}$ & 42,65 & \multirow{2}{*}{57} & $74,82 \%$ \\
\hline & & NF & 35,04 & & $61,49 \%$ \\
\hline \multirow[t]{2}{*}{4.} & \multirow{2}{*}{$\begin{array}{l}\text { Kesiswaan dan Ekstra } \\
\text { kurikuler }\end{array}$} & $\mathrm{F}$ & 36,33 & \multirow{2}{*}{57,33} & $63,34 \%$ \\
\hline & & NF & 30,70 & & 53,55 \\
\hline \multirow[t]{2}{*}{5.} & \multirow{2}{*}{$\begin{array}{l}\text { Kemitraan Sekolah } \\
\text { dengan Masyarakat }\end{array}$} & $\mathrm{F}$ & 30,92 & \multirow{2}{*}{39} & $79,28 \%$ \\
\hline & & NF & 24,42 & & $62,62 \%$ \\
\hline
\end{tabular}

k. Korelasi Antarskor Setiap Responden pada Setiap Layanan. Dengan menggunakan program SPSS maka korelasi antara skor setiap responden pada setiap layanan diperoleh data sebagai berikut.

1. Layanan Pembelajaran (Kurikuler dan Kokurikuler). Pada layanan pembelajaran (kurikuler dan kokurikuler) korelasi antara responden kepala sekolah dengan guru mata pelajaran adalah $0,481(\mathrm{p}=0,01)$, sementara dengan siswa adalah $0,548(\mathrm{p}=0,01)$. Hasil korelasi ini menunjukkan bahwa skor setiap penilai terhadap layanan pembelajaran memiliki korelasi yang tinggi sehingga dapat disimpulkan bahwa instrumen layanan pembelajaran memiliki konsistensi yang baik pada setiap responden penilainya.

2. Manajemen dan Iklim Sekolah. Pada layanan manajemen dan iklim sekolah korelasi antara responden kepala sekolah dengan guru mata pelajaran adalah $0,460(\mathrm{p}=0,01)$, sementara dengan siswa adalah $0,479(\mathrm{p}=0,01)$. Korelasi antar skor guru mata pelajaran dengan siswa adalah 0,799 $(\mathrm{p}=0,01)$. Hasil korelasi ini menunjukkan bahwa skor setiap penilai terhadap layanan manajemen dan iklim sekolah memiliki korelasi yang tinggi sehingga dapat disimpulkan bahwa 
instrumen layanan manajemen dan iklim sekolah memiliki konsistensi yang baik pada setiap responden penilainya.

3. Layanan Bimbingan dan Konseling. Pada layanan bimbingan dan konseling, hasil perhitungan SPSS menunjukkan korelasi antara skor responden kepala sekolah dengan guru mata pelajaran adalah 0,422 $(\mathrm{p}=0,01)$ dengan guru pembimbing adalah $0,331(\mathrm{p}=0,01)$ sementara dengan siswa adalah $0,452(\mathrm{p}=0,01)$. Korelasi antara skor guru mata pelajaran dengan skor siswa adalah $0,575(\mathrm{p}=0,01)$, sementara korelasi skor guru mata pelajaran dengan skor guru pembimbing $0,799(\mathrm{p}=0,01)$ dan skor guru pembimbing dengan siswa adalah $0,629(\mathrm{p}=0,01)$. Hasil perhitungan ini menunjukkan bahwa layanan bimbingan dan konseling memiliki korelasi yang tinggi pada antar responden, sehingga dapat disimpulkan bahwa layanan ini memiliki konsistensi yang tinggi sebagai instrumen yang dapat digunakan untuk setiap responden.

4. Layanan Kesiswaan dan Ekstrakurikuler. Hasil perhitungan SPSS pada skor layanan kesiswaan dan ekstrakurikuler untuk setiap responden menunjukkan bahwa korelasi antar skor kepala sekolah dengan skor wakasek/guru pembina kesiswaan adalah $0,169(\mathrm{p}=0,01)$ sementara dengan siswa adalah $0,363(\mathrm{p}=0,01)$. Korelasi antara skor wakasek/guru pembina kesiswaan dengan skor siswa adalah $0,734(p=0,01)$. Hasil korelasi antar skor responden dalam layanan kesiswaan tidak menunjukkan korelasi yang konsisten.

5. Layanan Kemitraan dengan Masyarakat. Dengan menggunakan program SPSS, korelasi antar responden pada layanan kemitraan dengan masyarakat adalah sebagai berikut. Korelasi skor antara kepala sekolah dengan skor siswa adalah $0,377(\mathrm{p}=0,01)$, korelasi dengan orang tua siswa adalah $0.306(\mathrm{p}=0,01)$ sementara dengan guru mata pelajaran adalah $0,511(\mathrm{p}=0,01)$, sementara dengan guru mata pelajaran adalah $0,433(\mathrm{p}=0,01)$. Korelasi antara skor guru mata pelajaran dengan orang tua adalah $0,350(\mathrm{p}=0,01)$. Keseluruhan hasil korelasi ini menunjukkan bahwa instrumen layanan kemitraan dengan masyarakat memiliki konsistensi sebagai instrumen untuk setiap responden yang melakukan penilaian. 
1. Analisis Hasil Uji Coba dan Revisi Instrumen. Secara keseluruhan instrumen untuk setiap layanan tidak mengalami pengurangan penjumlahan karena beberapa item yang kurang baik masih dapat diperbaiki dengan melakukan perubahan seperlunya, sehingga dapat dipergunakan kembali. Hasil akhir instrumen untuk setiap layanan pada setiap responden angket adalah sebagai berikut.

Memperhatikan hasil uji beda setiap layanan dengan membedakan sekolah favorit dan nonfavorit seluruh instrumen menunjukkan sebagai instrumen yang valid untuk membedakan keefektifan setiap layanan antara sekolah favorit dan nonfavorit. Bila dilihat dari skor total diperoleh informasi bahwa kelima layanan yaitu layanan pembelajaran, manajemen dan iklim sekolah, bimbingan dan konseling, kesiswaan dan ekstrakurikuler serta kemitraan dengan masyarakat menunjukkan perbedaan yang signifikan antara sekolah favorit dengan nonfavorit. Informasi lain yang dijadikan dasar dalam memberikan skor terhadap keefektifan setiap layanan adalah korelasi antar skor setiap responden yang tinggi. Hasil korelasi yang tinggi ditunjukkan oleh kelima layanan tersebut. Hasil ini membawa implikasi terhadap perhitungan skor efektivitas bagi setiap layanan. Perhitungan efektivitas bagi layanan pembelajaran, manajemen dan iklim sekolah, bimbingan dan konseling, kesiswaan dan ekstrakurikuler, serta kemitraan dengan masyarakat dihitung sebagai rata-rata dari skor setiap responden yang menilai terhadap sesuatu layanan tersebut. Selanjutnya, perhitungan tingkat efektivitas baik setiap layanan beserta aspeknya maupun suatu sekolah ditentukan dengan suatu rumus yang dijabarkan di dalam pedoman penilaian.

\section{Sistem Penilaian Sekolah Efektif}

Rumusan tentang sistem penilaian sekolah efektif meliputi hal-hal sebagai berikut: (1) Dasar pemikiran tentang perlunya tujuan penilaian sekolah efektif; (2) Penjelasan tentang konstruk yang didasarkan pada empat kompetensi (keagamaan, akademik, ekonomi dan sosial pribadi). Selanjutnya, konstruk tersebut diturunkan menjadi indikator dengan memperhatikan fungsi lain dari layanan yang seharusnya diberikan oleh sekolah yang meliputi lima layanan (pembelajaran, manajemen dan iklim sekolah, bimbingan dan konseling, kesiswaan dan ekstrakurikuler, serta kemitraan dengan masyarakat). 
Rumusan akhir dari konstruk sekolah efektif menghasilkan seperangkat intrumen yang terdiri dari angket, pedoman wawancara dan observasi. Angket merupakan instrumen utama untuk setiap layanan, sementara pedoman wawancara ditujukan untuk layanan manajemen dan iklim sekolah, pembelajaran, kesiswaan dan ekstrakurikuler, serta kemitraan dengan masyarakat. Pedoman observasi digunakan untuk mengamati sarana yang mendukung layanan bimbingan dan konseling serta kesiswaan dan ekstrakurikuler; (3) Mekanisme dan prosedur pelaksanaan penilaian sekolah efektif yang meliputi mekanisme pelaksanaan penilaian baik yang dilakukan oleh sekolah sendiri sebagai self evaluation maupun yang akan dilaksanakan oleh pihak di luar sekolah. Prosedur pelaksanaan penilaian diuraikan mulai: (a) persiapan yang perlu dilakukan dan unsur yang terlibat dalam penilaian; (b) pengumpulan, analisis dan interpretasi data; (4) Pelaporan dan penetapan hasil penilaian, dan bagian terakhir memuat tentang (5) pemanfaatan hasil penilaian bagi upaya peningkatan efektivitas sekolah bagi kepala sekolah; guru dan staf sekolah; Depdiknas, Dinas Pendidikan daerah atau lembaga sejenis lainnya serta orang tua dan masyarakat.

\section{Pedoman Pelaksanaan Penilaian Sekolah Efektif dan Penafsirannya}

Pedoman pelaksanaan penilaian Sekolah Efektif memuat tentang beberapa hal yang berkaitan dengan pelaksanaan penilaian seperti berikut ini: (1) Tujuan tentang penilaian sekolah efektif dan fokus penilaian; (2) Penjelasan tentang instrumen yang digunakan untuk menilai layanan pembelajaran, manajemen dan iklim sekolah, bimbingan dan konseling, kesiswaan dan ekstra kurikuler, serta kemitraan dengan masyarakat; dan (3) Prosedur pelaksanaan penilaian yang meliputi persiapan, pelaksanaan, pengolahan, penafsiran dan pemanfaatan hasil penilaian.

\section{Usulan Implementasi Penilaian Sekolah Efektif}

Dasar pemikiran yang telah diuraikan sebelumnya tentang pentingnya penilaian sekolah bagi pengembangan program dan rencana sekolah harus sesuai dengan kebutuhan dan kondisi sekolah. Tujuan dan hasil penilaian yang ingin dicapai oleh sekolah adalah untuk mengetahui tingkat efektivitas dari optimalisasi setiap fungsi yang dijalankan oleh sekolah sebagai tempat 
belajar. Hasil penilaian diharapkan dapat digunakan untuk kepentingan sekolah (kepala sekolah dan guru) dan pihak luar yang melakukan penilaian untuk perbaikan sekolah misalnya Depdiknas tingkat Kabupaten/Kota, Proipinisi, dan masyarakat.

Ruang lingkup dan jenis instrumen penilaian meliputi layanan pembelajaran, manajemen dan iklim sekolah, bimbingan dan konseling, kesiswaan dan ekstrakurikuler dan kemitraan dengan masyarakat. Adapun instrumen penilaian meliputi angket untuk kepala sekolah, wakasek kesiswaan/guru pembinaan kesiswaan, guru mata pelajaran, guru pembimbing, siswa dan untuk orang tua. Instrumen lainnya adalah berupa pedoman observasi dan wawancara yang digunakan oleh pihak di luar sekolah untuk mendukung penilaian yang telah dilakukan oleh pihak luar sekolah.

Strategi pelaksanaan penilaian diuraikan tentang organisasi pelaksana penilaian, waktu pelaksanaan, langkah-langkah kegiatan penilaian mulai persiapan, pelaksanaan, analisis data dan pelaporan. Pelaksanaan penilaian melibatkan pembiayaan penilaian yang meliputi alokasi yang dibutuhkan untuk setiap pelaksanaan penilaian di suatu sekolah serta sumber pembiayaannya.

\section{Simpulan dan Saran}

\section{Simpulan}

Rangkaian kegiatan yang telah dilakukan dalam pengembangan Model Penilaian Sekolah Efektif (MPSE) telah ditempuh melalui kajian teori dan validasi lapangan. Kajian teori melalui penelaahan buku dan diskusi kelompok terfokus menghasilkan pengertian efektivitas sekolah sebagai optimalisasi fungsi-fungsi layanan sekolah baik yang berkaitan dengan sumber daya manusia maupun sumber-sumber daya lainnya dalam memfasilitasi kompetensi yang harus dikuasai oleh siswa. Kompetensikompetensi tersebut terdiri atas kompetensi keagamaan, kompetensi akademik, kompetensi ekonomi, dan kompetensi sosial-pribadi.

Kajian validasi lapangan dapat dilihat dari konteks pelayanan sekolah. Bentuk pelayanan ini perlu diberikan kepada siswa yang memiliki fungsi 
sebagai tempat untuk belajar bagi siswa sekolah perlu memberikan layanan pembelajaran, layanan manajemen dan iklim sekolah, layanan bimbingan dan konseling, layanan kesiswaan dan ekstrakurikuler, serta layanan kemitraan dengan masyarakat. Instrumen yang disusun untuk menilai setiap layaanan diberikan kepada subjek yang melaksanakan salah satu fungsi pelayanan, selain itu juga diberikan kepada responden lain yang bertindak sebagai atasan, teman sejawat, serta yang merasakan dan mengalami layanan tersebut. Dengan demikian, diharapkan akan muncul penilaian yang bersifat subjektif dan objektif untuk kemudian akan menjadi pertimbangan dalam menentukan skor akhir suatu layanan tertentu.

Dengan memperhatikan berbagai layanan dan responden yang menilai layanan tersebut, terumuskan suatu formula yang dapat dijadikan nilai dari tingkat efektivitas suatu sekolah. Formula ini dirumuskan dalam Pedoman Penilaian Sekolah Efektif. Pedoman ini dapat dimanfaatkan daerah dalam rangka menunjang semangat otonomi daerah serta kebijakan untuk menerapkan sistem manajemen yang berbasis sekolah. Jika para pengelola pendidikan merupakan tuntutan dalam mengelola sendiri sekolahnya masing-masing, maka penilaian efektivitas sekolah merupakan hal yang sangat fundamental untuk mengetahui pencapaian dari setiap layanan. Hasil ini dapat dijadikan landasan untuk melakukan perbaikan dan peningkatan pada setiap layanan dalam mencapai target yang diharapkan sesuai dengan kondisi yang ada. Hasil pertimbangan para akademisi yang terlibat dalam seminar dan lokakarya maupun validasi para praktisi dan penggunaan suatu layanan, instrumen yang disusun merupakan instrumen yang layak untuk digunakan disertai dengan Pedoman Penilaian Sekolah Efektif dan usulan pengembangan model implementasinya.

\section{Saran}

Berdasarkan hasil uji coba di lapangan, seperangkat instrumen MPSE dapat dijadikan standar dalam pelaksanaan peningkatan fungsi-fungsi sekolah baik yang menyangkut layanan pembelajaran, layanan manajemen dan iklim sekolah, layanan bimbingan dan konseling, layanan kesiswaan dan ekstrakurikuler, serta layanan kemitraan dengan masyarakat. Dengan demikian, MPSE perlu disosialisasikan ke sekolah-sekolah dan lembaga terkait untuk dapat dilaksanakan sesuai dengan tujuannya. 
Perlu dilembagakan MPSE, baik melalui pendekatan evaluasi diri (self/internal evaluation) oleh sekolah maupun oleh pihak luar. Agar penilaian sekolah efektif berdaya guna dan secara efisien dapat dilakukan oleh sekolah, maka perlu dilembagakan Komite Penilai Sekolah Efektif yang berisi unsur-unsur pemerintah daerah, pengelola, staf sekolah, masyarakat, perguruan tinggi dan para ahli.

\section{DAFTAR PUSTAKA}

Barrow, R. 1986. The Philosophy of Schooling. Brighton: Wheatsheaf Book Ltd.

Brighthouse, J. \& Woods, D. 1999. How to Improve Your School. New York: Routledge.

Cheng, Y.C. 1994. Planning and Structuring for Development and Effectiveness. Hong Kong, The Chinese University of Hong Kong.

Darling-Hammond, L. 1992. Professional Development Schools. New York: Teachers College Press.

Dunham, J. 1995. Developing Effective School Management. New York: Routledge.

Levine, M. (Ed.). 1994. Professional Practices Schools. New York: Teachers College Press.

Murgatroyd, S. \& Morgan, C. 1993. Total Quality Management and The School. Open University Press, Buckingham, PA.

O’Neil, John. 1995. On School as Learning Organizations. Educational Leadership.52(7)

Satori, D. 1995. Masalah Mutu Pendidikan. Makalah diskusi pendidikan bersama Kepala Sekolah dan Guru-guru di YP-PGII pada tanggal 11 Juli di Bandung.

Taylor, B.O. (Ed.). 1990. Case Studies in Effective Schools Research. Kendal/Hunt Publishing Company.

The World Bank 1998. Education in Indonesia: From Crisis to Recovery. Education Sector Unit, East Asia and Pacific Regional Office. 